\title{
Hubungan Efikasi Diri dengan Kematangan Karir Siswa
}

\author{
Lorensia Claudia Charista $^{1 *}$, Yari Dwi Kurnaningsih², Tritjahyo Danny Soesilo³,
}

1 Jurusan Bimbingan dan Konseling Universitas Kristen Satya Wacana Salatiga, Indonesia

${ }_{2}^{2}$ Jurusan Bimbingan dan Konseling Universitas Kristen Satya Wacana Salatiga, Indonesia

3 Jurusan Bimbingan dan Konseling Universitas Kristen Satya Wacana Salatiga, Indonesia

\begin{abstract}
Abstrak
Jenis penelitian ini adalah penelitian korelasional yang bertujuan untuk menguji hubungan antara efikasi diri dengan kematangan karir. Hipotesis yang diajukan dalam penelitian ini adalah ada hubungan yang signifikan antara efikasi diri dengan kematangan karir. Subjek yang digunakan dalam penelitian ini sebanyak 181 siswa kelas X SMK PGRI 2 Salatiga. Pengumpulan data menggunakan dua jenis skala, yaitu skala efikasi diri dan skala kematangan karir. Teknik analisis data yang digunakan dalam penelitian ini menggunakan korelasi kendall's tau-b, dan pengolahan datanya menggunakan progam SPSS for Windows 20.0 version. Hasil penelitian menunjukkan bahwa ada hubungan yang signifikan antara efikasi diri dengan kematangan karir pada siswa kelas X di SMK PGRI 2 Salatiga ditunjukkan nilai $r=0,928$ dengan taraf signifikan $0,000 \leq 0,05$.
\end{abstract}

\begin{tabular}{l} 
Keywords: \\
\hline efikasi diri, \\
kematangan karir, \\
siswa kelas X SMK
\end{tabular}

\section{PENDAHULUAN}

Karena siswa SMK dipersiapkan untuk terjun ke dunia kerja segera setalah mereka lulus, siswa SMK harus memiliki kematangan karir dan pilihan karir sehingga mereka memiliki daya saing yang kuat di dunia kerja. Jika siswa tidak memiliki kematangan karir, maka dapat menyebabkan kesalahan dalam pengambilan keputusan karir.

Dalam upaya pemilihan karir, peserta didik perlu memiliki kesadaran tentang dirinya atau mengetahui konsep diri mereka sendiri. Super (dalam Santrock, 2007:172) mengatakan bahwa pemilihan karir merupakan implementasi dari konsep diri. Disini, konsep diri yang memiliki hubungan dengan perkembangan karir seseorang adalah self efficacy atau kepercayaan diri untuk menguasai suatu situasi dan menghasilkan sesuatu yang baik. Dalam proses pemilihan karir, penting bagi individu untuk menentukan tujuan, sejauh mana individu tersebut memperjuangkan target yang ia miliki, dan sekuat apa ia mampu mengatasi masalah yang muncul, termasuk setangguh apa ia mampu menghadapi kegagalan. Individu yang memiliki tujuan yang kuat, akan memiliki dorongan yang kuat untuk bekerja lebih giat, serta lebih tahan dalam mengatasi kesulitan dan lebih mampu mencapai level prestasi yang lebih tinggi dan lebih baik.

Dalam penelitian sebelumnya, Susantoputri, Kristina, dan Gunawan (2014) menemukan bahwa ada hubungan positif yang signifikan antara efikasi diri karier dengan kematangan karier pada remaja di kota Tangerang. Hasil ini berbeda dengan temuan Wijanti dan Karyanta (2012) yang menunjukkan bahwa ada hubungan yang lemah dan tidak signifikan antara keyakinan diri dengan kematangan karier pada siswa SMK Muhammadiyah 2 Andong Boyolali.

Dalam penelitian ini, penulis telah melakukan tahapan pra-wawancara dengan guru Bimbingan Konseling (BK) SMK PGRI 2 Salatiga kelas X, tempat penelitian dilakukan. Guru tersebut menyatakan bahwa layanan bimbingan dan konseling kepada siswa kelas X masih belum maksimal karena fokus layanan mengenai bimbingan karir diberikan pada siswa kelas XII yang akan segera lulus dan memasuki dunia kerja. Lebih lanjut lagi, guru BK menyatakan bahwa siswa yang lulus banyak yang bekerja sesuai jurusan yang diambil sewaktu di SMK, walaupun tidak sedikit pula yang bekerja tidak sesuai dengan jurusan mereka karena ketatnya persaingan di dunia kerja, faktor lingkungan, dan keluarga yang tidak memperbolehkan mereka bekerja jauh dari rumah. Pra-wawancara juga dilakukan dengan siswa SMK PGRI 2 dimana ia menyatakan bahwa informasi yang diberikan pihak sekolah mengenai peluang karir

\footnotetext{
* Corresponding author.

E-mail Addresses: - deac74@gmail.com (Lorensia Claudia Charista), yari.dwikurnaningsih@staff.uksw.edu (Yari Dwi Kurnaningsih), tritjahjo.danny@staff.uksw.edu (Tritjahyo Danny Soesilo)
} 
yang sesuai dengan jurusan siswa masih dirasa kurang sehingga mereka harus mengandalkan informasi dari orang tua ataupun teman.

Satu hal yang para siswa hiraukan saat melakukan pencarian kerja adalah untuk menggali lebih dalam lagi kemampuan yang ada pada diri mereka. Seharusnya, siswa memiliki kemampuan untuk dapat menemukan dan mengetahui potensi yang mereka miliki sebagai bekal karir di masa yang akan datang.

Dari penjabaran tersebut, jelas terdapat berbagai masalah mengenai kematangan karir yang berkaitan dengan efikasi diri di SMK PGRI 2 Salatiga, sehingga penulis ingin menjawab pertanyaan adakah hubungan yang signifikan antara efikasi diri dengan kematangan karir siswa kelas X di SMK PGRI 2 Salatiga.

Diharapkan bahwasanya penelitian ini dapat bermanfaat bagi perkembangan ilmu pengetahuan dan menjadi acuan untuk peneliti-peneliti selanjutnya dengan memperkaya kajian ilmiah dalam bidang Bimbingan dan Konseling, khususnya mengenai efikasi diri dan kematangan karir. Lebih lanjut lagi, beberapa manfaat praktis juga diharapkan dapat dicapai, khususnya bagi guru, dimana guru dapat memberikan materi kepada para siswa didiknya sehingga mereka dapat memiliki pemahaman yang baik mengenai efikasi diri mereka dan potensi yang mereka miliki. Selain itu, guru juga dapat memperikan pendekatan khusus bagi peserta didik yang memiliki kematangan karir yang rendah untuk dapat menemukan potensi mereka sehingga akan memudahkan siswa dalam menentukan karirnya di masa yang akan datang, sesuai dengan bakat, minat, dan kemampuan masing-masing.

\section{METODE PENELITIAN}

Penelitian ini adalah penelitian kuantitatif dan berjenis korelasional. Penelitian kuantitatif adalah salah satu jenis penelitian yang spesifikasinya adalah sistematis, terencana, dan terstruktur dengan jelas sejak awal hingga pembuatan desain penelitiannya. Menurut Sugiyono (2013:13) metode penelitian kuantitatif dapat diartikan sebagai metode penelitian yang berlandaskan pada filsafat positivisme, digunakan untuk meneliti pada populasi atau sampel tertentu, teknik pengambilan sampel pada umunya dilakukan secara random, pengumpulan data menggunakan instrumen penelitian, analisis data bersifat kuantitatif/statistik dengan tujuan untuk menguji hipotesis yang telah ditetapkan. Sedangkan yang dimaksud dengan korelasional adalah suatu penelitian untuk mengetahui hubungan dan tingkat hubungan antara dua variabel atau lebih tanpa adanya upaya untuk mempengaruhi variabel tersebut sehingga tidak terdapat manipulasi variabel (Fraenkel dan Wallen, 2008:328).

Variabel penelitian ini adalah efikasi diri (self efficacy) sebagai variabel $\mathrm{X}$ dan kematangan karir sebagai variabel Y. Variabel merupakan suatu atribut atau sifat atau nilai dari orang, obyek, atau kegiatan yang mempunyai variasi tertentu yang ditetapkan oleh peneliti untuk dipelajari dan ditarik kesimpulannya (Sugiyono, 2015).

Populasi dari penelitian ini adalah siswa-siswa kelas X SMK PGRI 2 Salatiga yang berjumlah 181siswa yang terbagi dalam 6 kelas. Sedangkan sampel Sampel yang akan digunakan dalam penelitian ini adalah random sampling. Random sampling adalah teknik pengambilan sampel yang dilakukan dengan cara mencampur subjek-subjek yang ada didalam populasi sehingga semua subjek dianggap sama (Suharsimi Arikunto, 2006:134). Cara pengambilan sampel menggunakan teknik Isaac dan Michael. Dalam penentuan jumlah sampel, ditentukan dengan menentukan jumlah kesalahan pada populasai antara 1\%, 5\%, dan 10\% pada tabel (Sugiyono, 2010:71). Selanjutnya untuk mendapatkan jumlah sampel per strata dihitung dengan menggunakan rumus jumlah populasi strata/jumlah populasi $\mathrm{x}$ jumlah sampel yang tertera pada tabel. Dalam penelitian ini, peneliti menggunakan tingkat kesalahan 5\% sehingga berdasarkan tabel (Sugiyono, 2010:71), dari populasi sebanyak 181 siswa didapat sampel sebanyak 123 siswa.

Metode pengumpulan data adalah cara yang digunakan peneliti dalam mengumpulkan data. Azwar (2009) menjelaskan bahwa metode pengumpulan data dalam kegiatan penelitian mempunyai tujuan untuk mengungkap fakta mengenai variabel yang diteliti. Data dalam penelitian ini diperoleh dari alat pengumpulan data berupa skala sikap. Skala sikap yang akan digunakan dalam penelitian ini meliputi skala kematangan karir dan skala efikasi diri. Dalam penelitian ini uji coba validitas instrumen dilakukan pada peserta didik kelas X B (Akuntansi dan Keuangan Lembaga), uji coba instrumen dilakukan satu kali sekaligus dua inventori kepada 30 peserta didik.

Berdasarkan hasil uji validitas item variabel efikasi diri terdapat 36 item (keseluruhan) tergolong valid dengan rentang koefisien korelasi 0,402 - 0,844. Sedangkan hasil uji validitas item variabel kematangan karir terdapat 44 item (keseluruhan) tergolong valid dengan rentang korelasi 0,422 - 0,843. 
Dengan demikian maka item variabel efikasi diri dan item variabel kematangan karir dinyatakan valid karena koefisien korelasi $\geq 0,20$.

Uji reliabilitas dilihat pada nilai Alpha-Croncbach untuk reliabilitas keseluruhan item dalam satu variabel. Pada variabel efikasi diri diperoleh hasil $\alpha=0,970$ dan pada variabel kematangan karir diperoleh hasil $\alpha=0,975$ sehingga instrumen dalam penelitian ini dapat dikatakan memiliki reliabilitas pada kategori sangat bagus. Dalam penelitian ini pengolahan data dianalisis dengan menggunakan progam SPSS For Windows versi 20. Teknik analisis data menggunakan teknik korelasi kendall's tau b, teknik ini digunakan untuk menampilkan hasil hubungan antara dua variabel yaitu variabel efikasi diri dan variabel kematangan karir. Teknik korelasi kendall's tau b ini digunakan untuk menganalisa signifikansi hubungan antara dua variabel diatas.

\section{ANALISIS DAN PEMBAHASAN}

Penelitian ini dilaksanakan pada bulan April - Mei 2018. Data yang diperoleh dalam penelitian ini merupakan hasil analisis dari skala efikasi diri dan skala kematangan karir. Skala ini digunakan untuk mengetahui tingkat efikasi diri dan tingkat kematangan karir yang dimiliki oleh peserta didik SMK PGRI 2 Salatiga. Peneliti mengkategorikan subyek penelitian menjadi lima, yaitu sangat tinggi, tinggi, sedang, rendah, dan sangat rendah.

Efikasi diri pada peserta didik diukur dengan menggunakan skala efikasi diri dengan menggunakan empat pilihan jawaban. Skala ini memiliki jumlah pernyataan sebanyak 36 butir dengan skor jawaban tertinggi 4 dan skor jawaban terendah 1 . Untuk mengetahui tingkat efikasi diri peserta didik dalam kategori sangat tinggi, tinggi, sedang, rendah, dan sangat rendah maka dapat dilihat pada tabel berikut:

Tabel 1. Distribusi Frekuensi Efikasi Diri

\begin{tabular}{llcc}
\hline Kategori & Interval & Frekuensi & Presentase (\%) \\
\hline Sangat tinggi & $124-145$ & 11 & $8,47 \%$ \\
Tinggi & $102-123$ & 44 & $33,84 \%$ \\
Sedang & $80-101$ & 58 & $46,61 \%$ \\
Rendah & $58-79$ & 8 & $6,15 \%$ \\
Sangat rendah & $36-57$ & 9 & $6,92 \%$ \\
Total & & 130 & $100 \%$ \\
Min & & & 36 \\
Max & & 145 \\
\hline
\end{tabular}

Berdasarkan tabel 1 diatas dapat diketahui bahwa peserta didik yang memiliki efikasi diri sangat tinggi sebesar 8,47\% dengan jumlah 11 peserta didik, kategori tinggi 33,84\% dengan jumlah 44 peserta didik, kategori sedang 46,61\% dengan jumlah 58 peserta didik, kategori rendah6,15\% dengan jumlah 8 peserta didik, dan kategori sangat tinggi 6,92\% dengan jumlah 9 peserta didik. Dari hasil distribusi frekuensi diatas terlihat bahwa efikasi diri peserta didik sebagian besar berada pada kategori sedang, dengan jumlah 58 peserta didik.

Kematangan karir pada peserta didik diukur dengan menggunakan skala kematangan karir dengan menggunakan empat pilihan jawaban. Skala ini memiliki jumlah pernyataan sebanyak 44 butir dengan skor jawaban tertinggi 4 dan skor jawaban terendah 1 . Untuk mengetahui tingkat kematangan karir peserta didim dalam kategori sangat tinggi, tinggi, sedang, rendah, dan sangat rendah maka dapat dilihat pada tabel dibawah ini :

Tabel 2. Distribusi Frekuensi Kematangan Karir

\begin{tabular}{|c|c|c|c|}
\hline Kategori & Interval & Frekuensi & Presentase (\%) \\
\hline Sangat tinggi & $152-178$ & 7 & $5,38 \%$ \\
\hline Tinggi & $125-151$ & 43 & $33,08 \%$ \\
\hline Sedang & $98-124$ & 62 & $47,69 \%$ \\
\hline Rendah & $71-97$ & 16 & $12,30 \%$ \\
\hline Sangat rendah & $44-70$ & 2 & $1,54 \%$ \\
\hline Total & & 130 & $100 \%$ \\
\hline Min & & & 44 \\
\hline
\end{tabular}


Berdasarkan tabel 2 diatas dapat diketahui bahwa peserta didik yang memiliki kematangan karir sangat tinggi sebesar5,38\% dengan jumlah 7 peserta didik, kategori tinggi 33,08\% dengan jumlah 43 peserta didik, kategori sedang 47,69\% dengan jumlah 62 peserta didik, kategori rendah12,30\% dengan jumlah 16 peserta didik, dan kategori sangat rendah 1,54\% dengan jumlah peserta didik 2. Dari hasil distribusi frekuensi diatas terlihat bahwa kematangan karir peserta didik sebagian besar berada pada kategori sedang, dengan jumlah 62 peserta didik.

Uji hipotesis bertujuan untuk mengetahui ada atau tidak ada hubungan (korelasi) antara efikasi diri dengan kematangan karir siswa kelas X di SMK PGRI 2 Salatiga. Pengujian korelasi menggunakan kendall's tau dengan menggunakan SPSS 20.0 for Windows, hasil uji korelasi dapat dilihat pada tabel 3 sebagai berikut:

Tabel 3. Uji Korelasi Kendall's Tau

\begin{tabular}{|c|c|c|c|c|}
\hline \multicolumn{5}{|c|}{ Correlations } \\
\hline & & & $X$ & \\
\hline \multirow[t]{12}{*}{ Kendall's tau_b } & EFIKASI DIRI & Correlation & 1 & \\
\hline & & Coefficient & .000 & 928 \\
\hline & & Sig. & . & \\
\hline & & tailed) & & 000 \\
\hline & & $\mathrm{N}$ & 1 & \\
\hline & & & 30 & 30 \\
\hline & KEMATANGAN & Correlation & & \\
\hline & KARIR & Coefficient & $928^{* *}$ & .00 \\
\hline & & Sig. & . & \\
\hline & & tailed) & 000 & \\
\hline & & $\mathrm{N}$ & 1 & \\
\hline & & & 30 & 30 \\
\hline
\end{tabular}

Berdasarkan hasil uji korelasi diatas maka diketahui nilai $r=0,928$ dengan taraf signifikan $0,000 \leq$ 0,05, dengan demikian dapat ditarik kesimpulan bahwa ada hubungan yang signifikan antara Efikasi Diri dengan Kematangan Karir siswa kelas X di SMK PPGRI 2 Salatiga.

Dilihat berdasarkan deskripsi data tabel kategorisasi tingkat efikasi diri terhadap kematangan karir siswa kelas X di SMK PGRI 2 Salatiga yang memiliki tingkat efikasi diri sangat rendah sebesar 6,92 \%, yang memiliki tingkat efikasi diri rendah sebesar 6,15\%, pada kategori sedang terdapat 44,61\%, pada kategori tinggi terdapat 33,85\%, dan pada kategori sangat tinggi terdapat 8,47\%. Dari paparan diatas menunjukkan bahwa secara rata-rata tingkat efikasi diri peserta didik terhadap karir pada siswa kelas $\mathrm{X}$ di SMK PGRI 2 Salatiga tergolong dalam kategori sedang. Hal ini menunjukkan bahwa peserta didik kelas $\mathrm{X}$ di SMK PGRI 2 Salatiga rata-rata sudah memiliki keyakinan atas kemampuan diri yang berhubungan dengan karir.

Variabel selanjutnya yaitu kematangan karir, menunjukkan hasil tingkat kematangan karir siswa kelas X di SMK PGRI 2 Salatiga pada kategori sangat rendah sebesar 1,54\%, kategori rendah sebesar $12,31 \%$, pada kategori sedang terdapat 47,69\%, pada kategori tinggi terdapat 33,08\%, dan pada kategori sangat tinggi terdapat 5,38\%. Dari paparan diatas dapat disimpulkan bahwa rata-rata peserta didik memiliki tingkat kematangan dan pengetahuan tentang karir yang sedang.

Efikasi diri merupakan salah satu konsep yang harus dimiliki oleh peserta didik dalam hal pemilihan karir. Karena seseorang yang memiliki efikasi diri yang tinggi cenderung akan lebih yakin ketika mengeksplorasi pilihan-pilihan karir yang menantang (Betz, 2004; Paulsen \& Betz, 2004; Quimby \& O’Brien, 2004; dalam Santrock, 2007 : 153). Hal ini sejalan dengan teori kognitif sosial karir yang dikembangkan oleh Hackett (dikutip Coertse \& Schepers, 2004:59) yang mengacu pada teori efikasi diri Bandura (1977) yang menyatakan bahwa pengembangan karir, pilihan karir, dan prestasi kerja memiliki hubungan dengan efikasi diri.

Dalam rangka memilih karir yang tepat dan sesuai dengan kemampuan yang dimiliki, peserta didik SMK membutuhkan kematangan karir yang baik karena tingkat kematangan karir mempengaruhi kualitas 
peserta didik dalam mempersiapkan dan memilih karirnya kelak di masa yang akan datang. Tetapi sebaliknya, rendahnya tingkat kematangan karir dapat menyebabkan kesalahan dalam pengambilan keputusan karir, termasuk kesalahan memilih dan menentukan jurusan keahlian. Sehingga dalam proses mempersiapkan karir, peserta didik perlu memiliki keyakinan tentang dirinya sendiri, yakin dengan kepribadian yang kuat dan menonjol, memiliki keyakinan akan potensi intelektualnya, dan megetahui kelebihan serta kelemahan yang dimiliki yang akan membuat dirinya berbeda dengan peserta didik yang lain. Peserta didik dapat menimbang berdasarkan potensi diri yang menyangkut bakat, minat, kemampuan, ciri khas, dan kepribadian yang mereka miliki. Hal inilah yang berhubungan dengan efikasi diri seperti yang dijelaskan diatas bahwa efikasi diri memiliki hubungan dengan kematangan karir.

Berdasarkan uji hipotesis yang telah dilakukan, menunjukkan hasil bahwa terdapat hubungan yang signifikan antara efikasi diri dengan kematangan karir pada siswa kelas X di SMK PGRI 2 Salatiga. Diketahui koefisien korelasi antara efikasi diri dengan kematangan karir sebesar 0,928 dengan demikian hipotesis alternativ diterima dan berbunyi terdapat hubungan yang signifikan antara efikasi diri dengan kematangan karir siswa kelas X di SMK PGRI 2 Salatiga.

Besarnya koefisien korelasi diatas dapat diartikan bahwa kedua variabel searah, apabila variabel X nilainya rendah, maka variabel Y rendah. Oleh karena itu, dapat disimpulkan bahwa terdapat hubungan yang signifikan antara efikasi diri dengan kematangan karir siswa kelas X di SMK PGRI 2 Salatiga. Berdasarkan hasil tersebut, maka semakin tinggi efikasi diri yang dimiliki peserta didik maka semakin tinggi pula kematangan karir yang dimiliki oleh siswa. Demikian pula sebaliknya semakin rendah efikasi diri pada peserta didik maka semakin rendah pula kematangan karir yang dimiliki oleh siswa di SMK PGRI 2 Salatiga.

Peserta didik yang memiliki efikasi diri yang tinggi akan mampu untuk membuat perencanaan karir yang meliputi (kognitif) dan dapat mengambil keputusan (afektif) terhadap karir yang diinginkan. Hal ini sejalan dengan yang dijelaskan bahwa peserta didik dengan efikasi diri tinggi cenderung lebih yakin ketika mengeksplorasi pilihan-pilihan karir yang menantang (Betz, 2004; Paulsen \& Betz, 2004; Quimby \& O’Brien, 2004; dalam Santrock, 2007:153). Ini sejalan dengan konsep yang telah dijelaskan oleh Schunk (1991, 2001, 2004; Schunk \& Zimmerman, 2003; Zimmerman \& Schunk, 2004; dalam Santrock, 2007:152) peserta didik dengan efikasi diri yang rendah, mungkin menghindari pekerjaan yang banyak tugasnya, khususnya seperti tugas-tugas yang menantang, namun sebaliknya peserta didik dengan efikasi diri yang timggi akan dapat menghadapi tantangan-tantangan tersebut dengan sangat antusias sekalipun pekerjaan itu sulit baginya.

Hasil penelitian diatas mendukung penelitian yang dilakukan oleh : Susantoputri, Kristina, dan Gunawan (2014) yang menunjukkan adanya hubungan positif yang signifikan antara efikasi diri karier dengan kematangan karier pada remaja di daerah kota Tangerang dengan hasil $r=0,456$ dengan $p<0,01$ dan juga penelitian Rishadi (2016) yang menunjukkan adanya hubungan positif yang signifikan antara efikasi diri dengan kematangan karir pada siswa kelas XI SMK Negeri 5 Pangkalpinang dengan hasil $r=$ 0,435 dengan $\mathrm{p}<0,00$.

\section{KESIMPULAN}

Berdasarkan dari hasil analisis data dan pembahasan yang telah diuraikan sebelumnya, penelitian ini membuktikan bahwa ada hubungan yang signifikan antara efikasi diri dengan kematangan karir. Hal ini ditunjukkan dengan koefesien korelasi $(r)$ sebesar 0,928 dan $p=0,000(p<0,05)$ yang mana 0,05 merupakan taraf signifikan, maka hubungan kedua variabel tersebut positif dan signifikan. Artinya semakin tinggi efikasi diri yang dimiliki oleh peserta didik maka semakin tinggi pula kematangan karir yang dimiliki. Namun sebaliknya, semakin rendah efikasi diri yang dimiliki oleh peserta didik maka semakin rendah pula kematangan karir yang dimilikinya. Dengan demikian hipotesis alternativ yang diajukan dinyatakan diterima.

Berdasarkan hasil penelitian yang telah dilakukan, maka terdapat beberapa saran dari peneliti untuk: 1) Bagi Guru BK disarankan untuk lebih banyak memberikan layanan bimbingan dan konseling terhadap peserta didik mengenai efikasi diri dan kematangan karir, bahkan sejak siswa masih di kelas X, sehingga siswa bisa mendapatkan informasi mengenai dunia pekerjaan atau perguruan tinggi, informasi karir, pengambilan keputusan karir, dan pandangan orientasi pada suatu bidang karir yang sesuai dengan bakat dan minat yang dimiliki oleh peserta didik. 2) Peserta Didik, Peserta didik diharapkan untuk untuk lebih yakin dan percaya dengan kemampaun yang dimiliki, tidak mudah menyerah dan berputus asa dalam menghadapi kegagalan, mampu untuk membuat perencanaan karir di masa yang akan datang, mampu untuk membuat keputusan karir, mampu mempersiapkan diri sejak dini untuk menghadapi 
persaingan di dunia kerja kelak, dan lebih aktif untuk mencari dan menggali informasi mengenai pilihan karir. 3) Peneliti Selanjutnya, Bagi peneliti selanjutnya yang akan melakukan penelitian serupa, penelitian ini dapat dijadikan tambahan referensi untuk penelitian selanjutnya.

\section{DAFTAR PUSTAKA}

Ali, M \& Mohammad Asrori. 2008. Psikologi Remaja Perkembangan Peserta Didik Cet 4. Jakarta: Bumi Aksara.

Alwisol. 2011. Psikologi Kepribadian. Malang: UMM Press.

Arikunto, S. 2006. Prosedur Penelitian Suatu Pendekatan Praktek. Jakarta: PT Rineka Cipta.

Azwar, S. 2003. Penyusunan Skala Psikologi Cet 12. Yogyakarta: Pustaka Pelalajar.

Azwar, S. 2009. Reliabbilitas dan Validitas. Yogyakarta: Pustaka Pelajar.

Bandura, Ablbert. 1997. Self efficacy in Changing Societes. New York: Cambrige University Perss.

Cervone, Daniel \& Parvin, Lawrence A. 2012. Kepribadian: Teori dan Penelitian. Terjemahan. Personality: Theory and Research. Tenth Edition. Penerjemah: Aliya Tusyani, dkk. Jakarta: Salemba Humanika.

Coertse, \& Schepers.2004. Some Personality and Cognitive Correlates of Career Maturity. Journal of industrial Psychology. Afrikaans University.

Corsini,RJ. 1994. Encyclopedia of Psychology. Second Edition. Vol. 3. New York: John Wiley and Sons.

Crite, J. 0. 1978. Theory and Research Handbook for Career Maturity Inventory. California:Montery.

Dariyo, A..2004. Psikologi Perkembangan Remaja. Bogor: Ghalia Indonesia.

Feist, J., \& Feist, G. J. 2009. Theories of Personality (7th ed.). New York: McGrawHill.

Feist,J.\& Gregory J. Feist.2010. Teori Kepribadian Theories Personality. Jakarta: Salemba Humanika.

Friedman, S. Howard dan Miriam, W. Schustack. 2009. Personality: Classic Theories and Modern Research Fourth Edition. United States of America: Pearson.

Gonzalez, M.A.2008. Career Maturity: a Priority for Secondary Education. Electronic Journal of Research in Educational Psychology. No. 16, Vol. 6 (3),749-772.

Muhammad Nur Gufron dan Rini Risnawita. 2010. Teori-teori Psikologi. Jakarta: Ar-Ruz Media.

Hartono. 2005. Psikologi Sosial. Yogyakarta: Pustaka Pelajar.

Hurlock, E. B. 2004. Psikologi Perkembangan: Suatu Pendekatan Sepanjang Rentang Kehidupan (Edisi Kelima). Jakarta: Erlangga.

Lau, P.L., Low, S.F., ZakariaA.R.2013. Gender and Work: Assesment and Application of Super's Theory Career Maturity. Jurnal Penelitian. Malaysia:Faculty of Education University of Malaya.

Latipun. 2002. Psikologi Eksperimen. Malang: UUM Press.

M. Ali \& M. Asori. 2005. Psikologi Remaja Perkembangan Peserta Didik. Jakarta. Bumi Aksara.

Nugraheni, I. 2011. Hubungan Antara Pusat Kendali Internal dengan Kematangan Karir Pada Siswa Kelas XII SMK Kristen I Klaten. Jurnal Penelitian Klaten: Fakultas Psikologi Universitas Ahmad Dahlan.

Patton, W. \& Lokan, J. 2001. Perspectives on Donald Super's Construct of Career Maturity. International Journal for Educational and Vocational Guidance, Vol 1, 31-48.

Santrock, J., W.2007. Remaja. Jilid 2, Alih Bahasa: Benedictine Widyasinta, Edisi ke-11, Jakarta: Erlangga.

Sharf, R.S. 1992. Applying Career Development Theory Of Counseling, California: Cole Publishing Company. 
Super, D. E. 1980. A Life-Span, Life-Space Approach to Career Development. Journal of Vocational Behavior 16. 282-298 Academic Press.Inc.

Sugiyono. 2010. Metode Penelitian Kuantitatif Kualitatif \& RND. Bandung:

Alfabeta.

Sugiyono. 2011. Metode Penelitian Kombinasi (Mixed Methods). Bandung: Alfabeta.

Sugiyono. 2015. Statistika untuk Penelitian. Bandung: Alfabeta

Supraptono, Eko. 1994. Kontribusi Minat Kejuruan dan Aspirasi Kerja Serta Status Sosial Ekonomi Orang Tua terhadap Kematangan Karir Siswa. Tesis Pasca Sarjana IKIP Bandung: Tidak Diterbitkan.

Suryabrata, Sumadi. 2006. Metode Penelitian. Jakarta: PT Raja Grafindo Persada.

Winkel, W. S dan Hastuti, S. 2007. Bimbingan dan Konseling di Institusi Pendidikan (Edisi Revisi, Cetakan Kelima). Yogyakarta: Universitas Sanatha Dharma.

Zunker, V. 2008. Career Counseling: A Hollistic Approach, 7th Edition. USA: Thomson Brooks. Cole 